\title{
Landslides and human interference in Darjiling Himalayas, India
}

\author{
Sunil Kumar DE ${ }^{1}$ \\ ${ }^{1}$ Department of Geography, North Eastern Hill University, Meghalaya, India \\ Received 24 November 2017; Revised 6 December 2017; Accepted 10 December 2017 \\ *Correspondence to: Sunil Kumar DE, e-mail: desunil@yahoo.com
}

\begin{abstract}
Landslides are among the nature's primarily ways of adjustment to slope stability. In Darjiling Himalayas the process has been intensified by human interference mainly through rapid deforestation, incorrect construction procedure and unplanned tapping of natural resources. The present paper aims at investigating the occurrence of landslides mainly due to human intervention. For analyzing the acuteness of the problem, important events of landslides over time, landslide susceptibility map using traditional check-list and investigation of the nature of human intervention for landslide occurrences have been carried out. From the study it is found that extreme rainfall events of consecutive days accumulating an amount of 1000 to $1200 \mathrm{~mm}$, coupled with deep weathering in susceptible structure could trigger to 5 to $10 \mathrm{~m}$-thick landslides. Being saturated with percolating rainwater, such slopes even with a rainfall 50 of $\mathrm{mm} / \mathrm{h}$ would cause disastrous landsllides. Common occurrence of landslides is found along the springs, where thick debris is removed along the slope, ontop of the bedrock.. Generally deforested urbanized tracts, illegal coal mining sites, tea gardens, artillery roads connecting hills with the plains are the most susceptible areas to sliding.
\end{abstract}

\section{KEYWORDS}

Slope stability; deforestation; incorrect construction; structural elements; joints and shear plane

\section{Introduction}

Landslides and related phenomena are the most serious natural hazard in the Darjiling Himalayas which undermine the overall socio-economic development of the area. From the past records it becomes apparent that the area has been suffering from landslide problems since 1899 and the situation has deteriorated further in recent time, particularly after India's independence (1947) and 
the last three decades (since 1968) have witnessed the most damaging landslide cases.. The Darjiling Himalaya, elevated at 2000-3000 m asl, extends at the foreland of the Kanchenjunga massif and are exposed directly to the invasion of humid air masses from the Bay of Bengal. The rising mountains with ever increasing human interferences create favourable conditions for rapid runoff, landslides and floods. The damages after heavy rains are extremely large. Landslides are known to be among the worst disaster phenomena in the concerned area. Even a glance at landslide statistics gives some idea of the enormity of damage done and the ever present threat to lives and property (Starkel and Basu, 2000). So far as the history is concerned, sliding was a minor physical phenomenon a hundred and fifty years ago. Ever since the British occupation, the physical and cultural set up of this region has been seriously disturbed. Tea plantations, extensive deforestation, hazardous construction works, inadequate drainage, in other words - unscientific and unplanned usage of land has led to the establishment of a vicious cycle of denudation, vulnerable geological structure along with heavy and concentrated rainfall enhancing soilerosion and landslides.

\section{Location and physical background of the study area}

The Darjiling Himalayas (Fig. 1) are located in the mountainous part of the Darjiling District above the $300 \mathrm{~m}$ contour line and is bounded by latitudes $26^{\circ} 50^{\prime} \mathrm{N}$ to $27^{\circ} 13^{\prime} 05^{\prime \prime} \mathrm{N}$ and longitudes $87^{\circ} 59^{\prime} 30^{\prime \prime}$ to $88^{\circ} 53^{\prime} \mathrm{E}$, comprising of an area of $2417 \mathrm{~km}^{2}$. They are including three hilly sub-divisions of Darjiling Sadar, Kalimpong and Kurseong and host a population of 790591 in 2011. In Darjiling Himalayas, landslides are long-time acknowledged as being the worst disaster phenomena which could inflict damages to human lives and properties.

The Darjiling Himalayas are separated from the foredeep of the Ganga-Brahmaputra plain by two active tectonic lines in the subduction zone of the Indian block (Fig. 2) and were built through a sequence of overthrusts pushed southwards and deepening to the north (Fig 3). Going southwards from the north there are the medium resistant Darjiling gneisses, the Daling metamorphic rocks of varying resistance, from phyllites to quartzites, and the Damuda shales with coal beds. The Damudas are separated by the Main Boundary Fault from the narrow thrust of Siwalik built of Tertiary sandy molassic deposits. The Siwaliks are separated by the active Himalaya Front Tectonic Line from the subsiding Bengal plain (Fig. 3). Some fresh tectonic scarps and exposures with the Tertiary overthrusts over the alluvium deposits indicate that the movement continues. The uplift in the Eastern Himalaya is calculated to be of the order of 0.5 to $2.0 \mathrm{~mm} / \mathrm{yr}$ (Starkel and Basu, 2000). The Darjiling Himalaya are rising directly over the piedmont plain called Terai composed by a system of alluvial fans. The edge of the hills is dissected with slopes inclined to $30-40^{\circ}$ and at a distance of $2 \mathrm{~km}$ from the piedmont plain rise to $600 \mathrm{~m}$ above it. The higher ridges are represented by hog backs, which are elevated to $1200 \mathrm{~m}$ a.s.l. at $6 \mathrm{~km}$ distance and to $2000 \mathrm{~m}$ a.s.l. at $12 \mathrm{~km}$

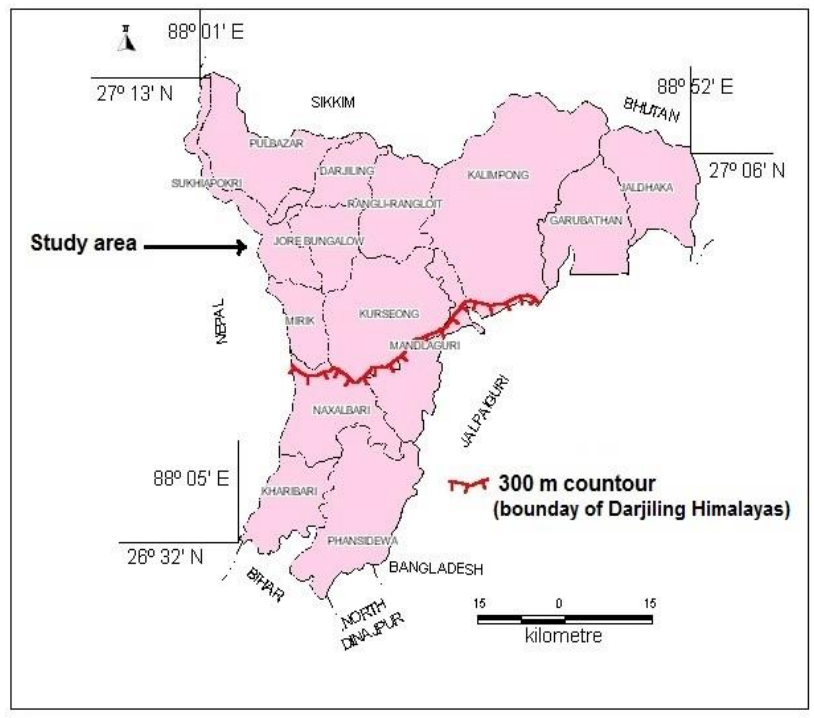

Figure 1 Location of the Darjiling Himalayas

In general young convex slopes with weakly developed concave basal part dominate the relief. Their steeper portions are inclined at $30-45^{\circ}$ and are mainly rocky; the more gentle slopes inclined at 15 $30^{\circ}$ are covered by regolith. But such simple slope profiles are relatively rare. 


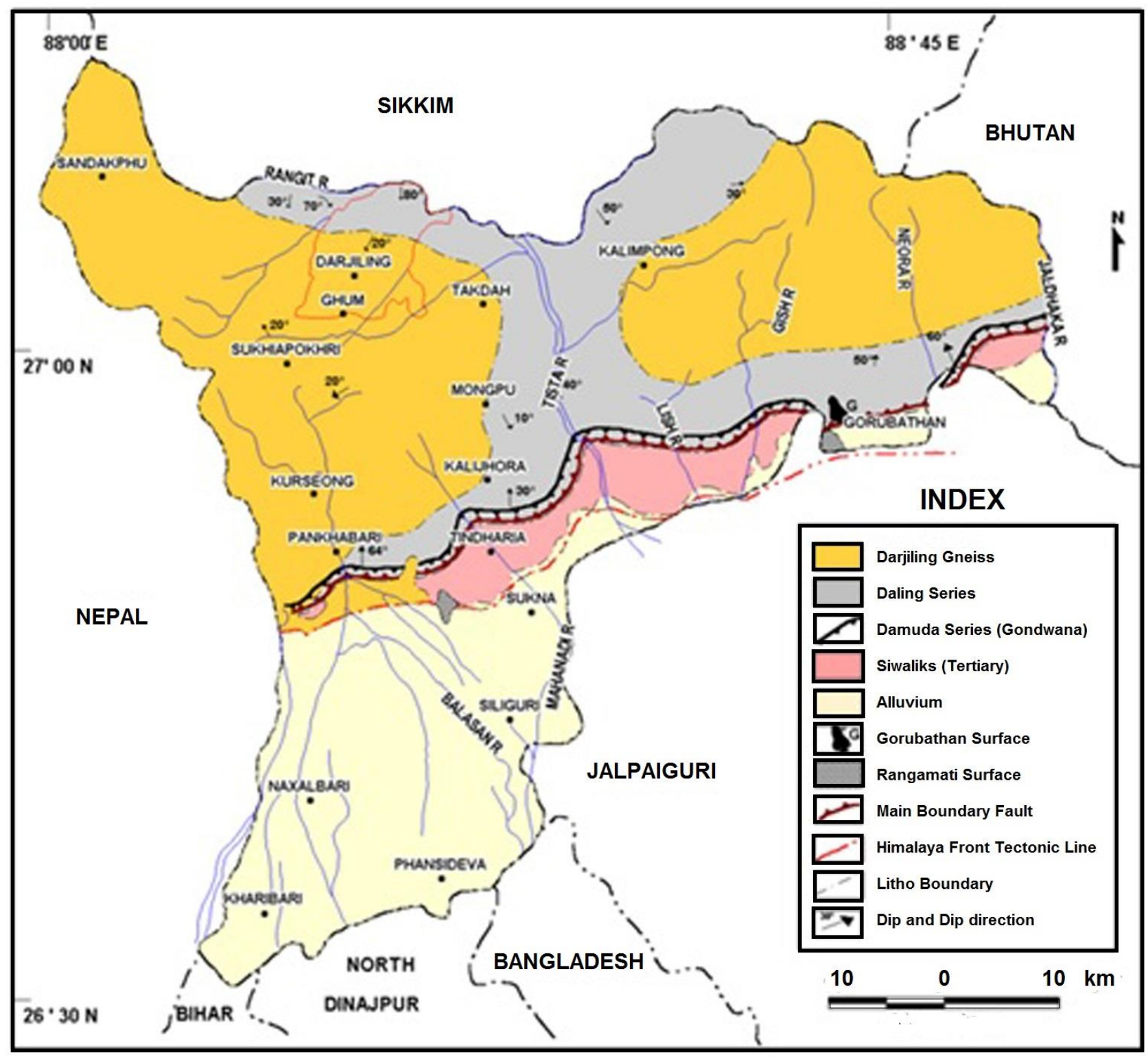

Figure 2 Geological Map of Darjiling District (modified after Ganssar, 1964)

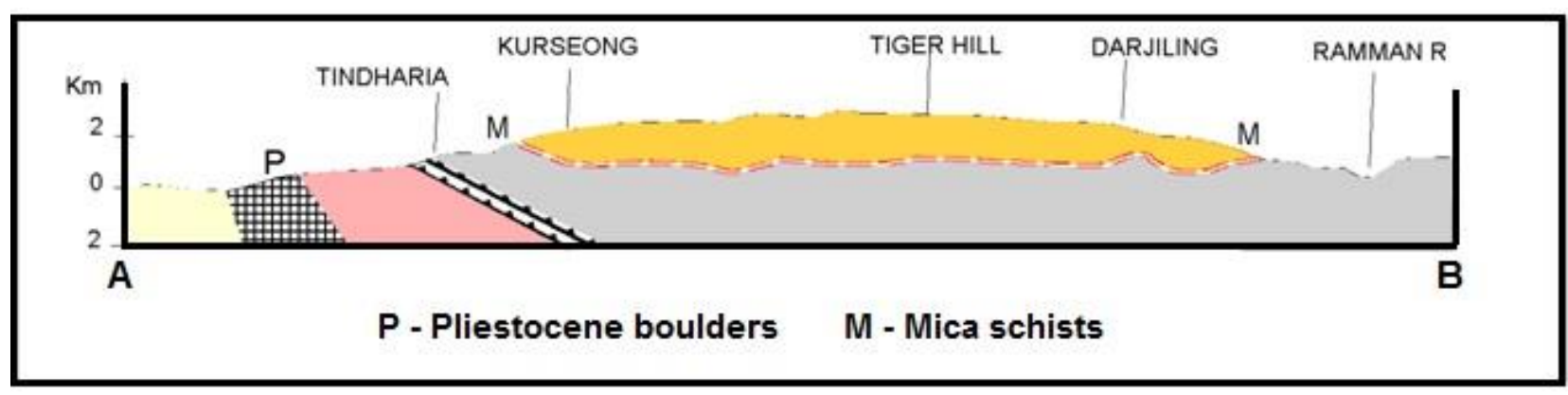

Figure 3 Cross section across the geological formations (modified after Ganssar, 1964) 
In general young convex slopes with weakly developed concave basal part dominate the relief. Their steeper portions are inclined at $30-45^{\circ}$ and are mainly rocky; the more gentle slopes inclined at $15-$ $30^{\circ}$ are covered by regolith. But such simple slope profiles are relatively rare. Very frequently on a single slope there are several scarps and flattening which are mainly structure-controlled and rarely reflect an older phase of planation (Froehlich, et al, 1989).

The major southern slope of the Himalaya lies at the margin of the high-pressure belt where seasonal migration of wind systems alters the weather and rainfall pattern. The summer monsoon starts in May and ends in September or early October. Beside seasonality, the second feature of climate in the Darjiling Himalayas is created by the orographic factor, causing the vertical zonation of temperature and other parameters and the decline of precipitation moving from the margin to the centre of the mountains (Froehlich, et al, 1987).

The annual precipitations fluctuate from 4000 $6000 \mathrm{~mm}$ at mountain front and then decline to $2000 \mathrm{~mm}$ north of Darjiling. In Darjiling there is a distinct seasonal distribution of rains. It fluctuates from several $\mathrm{mm}$ in winter months up to $400-800$ $\mathrm{mm}$ every month in summer. The number of days with rain in Darjiling is 124 (among them 102 from May to September).

The variable thickness of regolith and soils in the longitudinal slope profiles depends on the rate of weathering and intensity of mass movements connected with slope gradients. In many cases the thickest soil profiles are composed of in situ regolith and superimposed colluvial or proluvial deposits. The mountain slopes are covered with sandy-silty soils, usually 0.5 to 2.0 meter thick (on flat surfaces up to 4 meter). They change from red clay soil in the lowest elevation areas to grey brown forest soils in the higher elevations sectors. Soils are generally permeable but their thickness and physical parameters vary from place to place depending on the slope gradient, lithology of weathered bedrocks and land use.

\section{Population growth in the Darjiling Hill District}

Success of tea plantation, partition of Bengal, introduction of tourism and the resultant massive construction works (expansion of roads, construction of new urban structures etc.) ushered in more and more immigrants from the neighboring countries and thereby more than doubling the population of Darjiling Hill District (328785 persons) in 1951, while by 2011 the recorded population was of 790591 persons. The population density changed from 38 persons $/ \mathrm{km}^{2}$ in 1881 to 74 persons $/ \mathrm{km}^{2}$ in 1901 and 327 persons $/ \mathrm{km}^{2}$ in 2011 (Fig. 4).

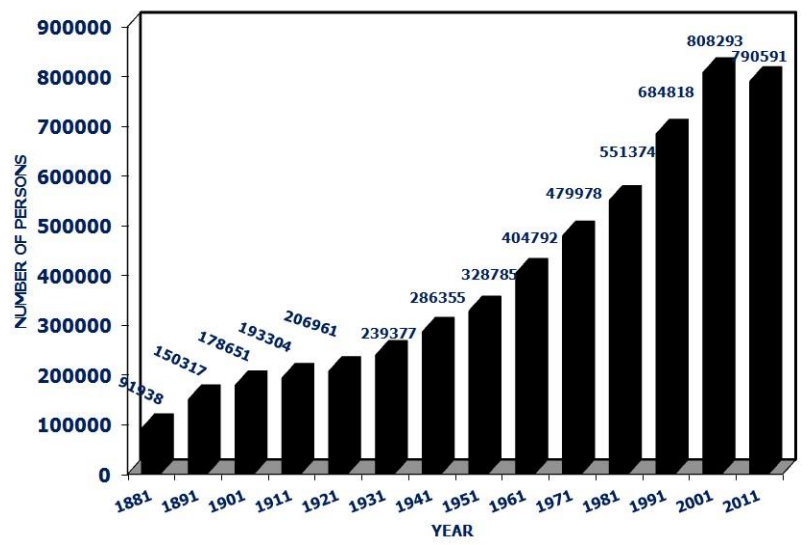

Figure 4 Decadal growth of population in Darjiling hill district

\section{Materials and methods}

The base map has been prepared from the Survey of India topographical sheets of 1:50,000 scale (Sheet nos. $78 \mathrm{~A} / 4,78 \mathrm{~A} / 8,78 \mathrm{~B} / 1,78 \mathrm{~B} / 5$ and $78 \mathrm{~B} / 6)$, Landslide spots have been plotted from the secondary data bases collected from the Geological survey of India, IRS P6- LISS III satellite image, Google Map images and from different published literatures. Field rectification of such slide spots has been done through extensive field survey with the help of handheld GPS.

Identification of landslide-prone areas has been performed with the help of a "Check-List" where each separate and discrete slope unit has been classified according to their stability rating. Rating 
has been done according to a scale from stable to already failed, through several degrees of of potential instability. Special attention has been paid to the old slides, which could become re-activated. The position and depth of different excavations, drainage diversion across the hills, loading of the upper/lower slopes, cutting of basal support, unscientific construction and land-use, deforestation, legacies from the past slope movement (landslide reactivations), relief unit, drainage characteristics, slope materials, etc. have been accounted for in the "Check-list". Data for such investigation have been collected from the direct field observation (82 sample sites) as well as from secondary sources, and a geomorphological map has been prepared for the landslide-prone areas.

Through the investigation of location and causative factors of such landslides it is found that rainfalls and earthquakes are the main triggering factors, but most of landslides have been taken place due to their preparation through human intervention. An analysis of landslide occurrences in different parts of Darjiling since its inception in 1899, reveals that the most common occurrence of landslides is found: $a$. along the springs which invariably cut across the roads, $b$. at illegal coal mining sites $c$. in tea gardens and $d$. in urban agglomerations. As such the present study has been restricted to those sites only. Therefore, the following case studies of individual landslides due to human intervention have been considered from different parts of the Darjiling Himalayas.

\section{Result and discussion}

\subsection{Landslide events in Darjiling}

From the available records it is found that disastrous landslips occurred during September 1899, January 1934, June ,1950, October 1968, September 1980, September 1991, July 1993 and July 1998 (Fig. 5). Such landslides caused widespread damage to human lives properties, roads, railways and cutoff the town from the rest of the region. Details of all these slides except 1998 are shown in Table. 1. The causes and consequences of the 1998 landslides have already been described along with the landslides related to the transportation routes heading to Darjiling by Basu, in 2000).

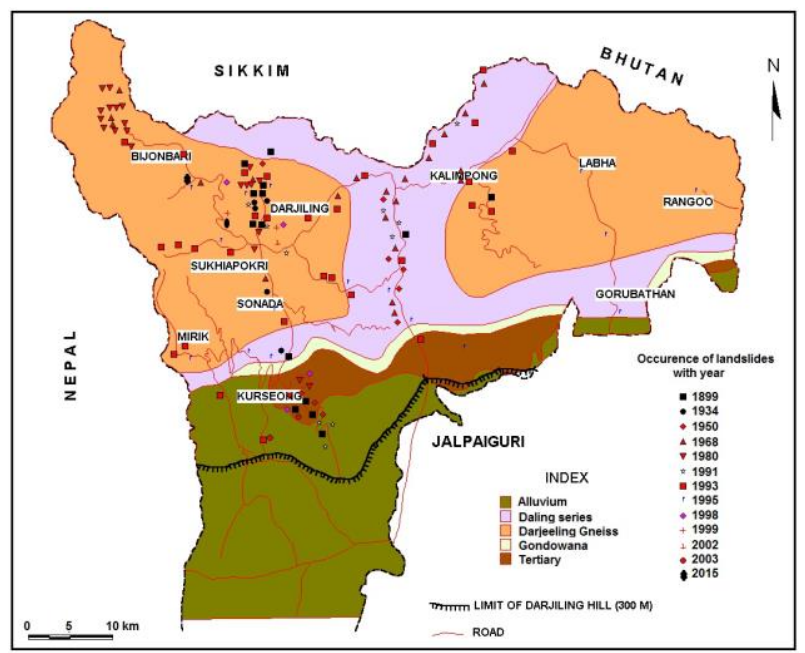

Figure 5 Distribution of landslides in different lithological formations

On July $8^{\text {th }}, 2003$ at about 3.30 a.m. a landslide occurred at Gayabari Bustee and four houses were destroyed and twelve lives were lost (especially due to the early hour). On July $7^{\text {th }}, 2004$ a series of devastating landslides crippled the tourist movement to Darjiling affecting the Hill Cart Road in several places. High rainfall ammount coupled with rock falls damaged the road along the Jhora crossings. Cracks on roads favored the flowing water to seep underground and caused subsidence. During July 1-2, 2015 continuous rainfall for more than 72 hours amounting $350 \mathrm{~mm}$ caused severe debris slides in Gayabari and Tinling tea gardens and tolled 68 lives as well as the destruction of 16 houses.

\subsection{Landslide susceptibility zonation}

From the detailed check-list and according to an expert judgement approach, the following three susceptibility zones have been demarcated based on the susceptibility values (Fig. 6 ).

i) High landslide prone areas: the TindhariaPaglajhora, Pankhabari, Rimbik-Lodhama, along the river Tista, Bijanbari, in and around Darjiling, Kurseong, Mahanadi, Ghum, Sonada, Sukhiapokri 
Landslides and human interference in Darjiling Himalayas, India

Table 1 Major events of landslips in Darjiling town and their effects

\begin{tabular}{|c|c|c|c|}
\hline PERIOD & LOCATION & TYPE & CAUSATIVE FACTOR \\
\hline January, 1897 & Tindharia Landslide & Subsidence - induced & Rainfalls \\
\hline $\begin{array}{l}\text { 23rd - 25th } \\
\text { September, } 1899\end{array}$ & $\begin{array}{l}\text { Tumsong, Margaret Hope } \\
\text { Landslides }\end{array}$ & Debris-slide & $\begin{array}{l}\text { Heavy and concentrated } \\
\text { rainfall }(1065.5 \mathrm{~mm}) \text { increasing } \\
\text { pore water pressure and } \\
\text { gravitational pool on the loose } \\
\text { materials }\end{array}$ \\
\hline 15th January, 1934 & $\begin{array}{l}\text { Sukhna and Tindharia } \\
\text { Landslides }\end{array}$ & Subsidence - induced & $\begin{array}{l}\text { A number of ground fissures } \\
\text { developed due to Bihar-Nepal } \\
\text { Earthquake }\end{array}$ \\
\hline 11th - 13th June, 1950 & Kurseong Landslide & $\begin{array}{l}\text { Debris slide along } \\
\text { a stream }\end{array}$ & $\begin{array}{l}\text { Heavy rainfall }(834 \mathrm{~mm}) \text { with } \\
\text { solifluction }\end{array}$ \\
\hline 11th - 13th June, 1950 & $\begin{array}{l}\text { Mirik and Gayabari } \\
\text { Landslide }\end{array}$ & Rock fall & $\begin{array}{l}\text { Heavy rainfall and gravitational } \\
\text { pull on loose rocks }\end{array}$ \\
\hline 2nd - 5th October, 1968 & Ambootia Landslide & Debris flow & $\begin{array}{l}\text { A big debris tongue carved out } \\
\text { a channel at least } 30-60 \mathrm{~m} \\
\text { deep due to heavy rainfall } \\
(890 \mathrm{~mm} .)\end{array}$ \\
\hline 7th July, 1985 & $\begin{array}{l}\text { Pankhabari Landslide (4.00 } \\
\text { km south of Kurseong) }\end{array}$ & Rock fall & $\begin{array}{l}\text { Heavy rainfall and gravitational } \\
\text { pull on loose materials }\end{array}$ \\
\hline 7th July, 1985 & $\begin{array}{l}\text { Pankhabari Landslide (4.20 } \\
\text { km south of Kurseong) }\end{array}$ & Debris slide & $\begin{array}{l}\text { Heavy rainfall, solifluction and } \\
\text { gravitational pull on loose } \\
\text { materials }\end{array}$ \\
\hline 8th July, 2003 & Gayabari Landslide & Debris slide & $\begin{array}{l}\text { A concentrated rainfall of over } \\
300 \mathrm{~mm} \text { during a period of } \\
\text { over } 48 \text { hours }\end{array}$ \\
\hline 16th August, 2009 & Gourisankar Landslide & Debris slide & $\begin{array}{l}\text { Torrential rain for a period of } \\
\text { more than } 70 \text { hours and flash } \\
\text { flood }\end{array}$ \\
\hline June 16, 2010 & Paglajohra Landslide & Debris slide & $\begin{array}{l}\text { Torrential rain of } 122 \mathrm{~mm} \text { from } \\
16 \text { to } 20 \text { June, } 2010\end{array}$ \\
\hline September, 2011 & Tindharia Landslide & Debris fall & Earthquake $\left(\mathrm{M}_{\mathrm{w}} 6.8\right)$ \\
\hline June,2012 & Tindharia Landslide & Debris slide & Torrential rainfall \\
\hline July 1-2, 2015 & Gayabari and Tinling Slide & Debris slide & Torrential rainfall \\
\hline
\end{tabular}

sectors are included in this zone, which occupies about 32\% of the Darjiling Himalayas hills.

ii) Moderately landslide prone areas: in this zone landslips occured once or twice in last ten years. The lower hills and the North facing slopes are showing moderate to moderately-low susceptibility and covers about $30 \%$ of the study area.

iii) Low landslide prone areas: the ridges having almost flat slopes are less susceptible to landslides. Both the hill top and lower parts towards the southern part of the study areas belong to this category which covers about $37 \%$ of the whole area.

\subsection{Human intervention on landslide events}

\subsubsection{Landslides along the transportation routes to Darjiling: Pagla Jhora}

Occurrence of landslides in Darjiling Himalayas is mainly found along the springs, which cut across the Hill Cart road as well as other roads connecting the hills with the plains. The most vulnerable site is situated in between the Upper and the Lower Pagla Jhoras (Fig.8), extending about $8 \mathrm{~km}$ in length. Here, the road has subsided at a maximum depth of about 7-9 m. since 1979 (Basu, 2001). 


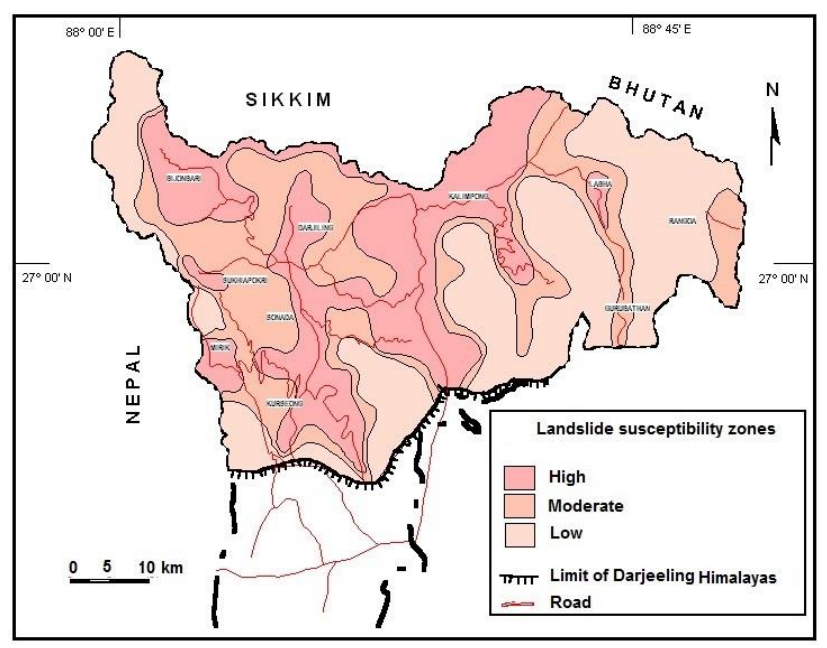

Figure 6 Landslide susceptibility zones of Darjiling Himalayas

The Hill-Cart road always provides a space for deposition of materials of the overflowing mountains torrents. The slope-wash materials consist of large boulders as well as fine-grained silt. The narrow culverts below the roads are inadequate to cope with the exceptionally high discharge of the springs during rains. Moreover, smooth passage of the discharges of the springs are sometimes temporarily blocked by the presence of boulders below the culverts until the rising water levels flow along available depressions on the road benches to create a new course diverting the spring away from their earlier established paths, causing loss of basal support and ultimately creates landslides. The damage of the road bench in all cases has been proportional to the discharge of the spring. Where the discharge exceeds the carrying capacity of the spring, the road bench also acts as a drainage channel. Cracks characterizing the road, allow the water to percolate below and erode the softer veins of rocks like phyllites and schists and thereby causing further subsidence along the road.

The Pagla Jhora and its tributaries with their exceptional discharges during $5^{\text {th }}$ to $7^{\text {th }}$ July, 1998 (Bhattacharya, et.al., 1998) due to high rainfall ammounts $(300-600 \mathrm{~mm}$ ) badly damaged the rail, cutting the road bridges from 37.5 to $45.5 \mathrm{~km}$ causing numerous landslides, due to bank undercut. The morphological configuration of the mentioned area is largely controlled by geological structure and the existing hydro-geomorphic process. Bedrock slopes are $35^{\circ}-43^{\circ}$ in inclination, uniform in pattern, partially stable and mostly free from sliding and slumping. The colluvial slope in the upper part consists of gigantic gneissic boulder of above $40 \mathrm{~m}$ in diameter. The size appears to be smaller (10-15 m in diameter) in the middle and lower parts. The slope form developed over such deposits is complex and exhibits a combination of convex-concaveirregular form with highly variable inclination $\left(10^{\circ}-\right.$ $25^{\circ}$ ). Field evidences suggest that the active mass movements including slumping at Pagla Jhora is directly related to this colluvial nature of hill slope.

Overland flow feeding the uppermost niche, during heavy rains, transforms into concentrated sub-surface flow over the less permeable gneissic bedrock. The observed rills and gullies facilitate the piping and deep drainage towards the slump areas. Thus, the subsurface flow is connected with the continuous beds in the colluvial sequence and jointing of bedrock. It is probably much higher during heavy rains with superimposition of an overland flow and seepage pressure. The flattening of topography suggests a subsurface run-off towards SSE direction.

The high intensity of the processes as well as the relative heights and steep gradients are the limiting factors in the stabilization of the Pagla Jhora slumps (Fig. 7). At present the form reached a quasiunstable equilibrium. Each extreme rainfall (> $300 \mathrm{~mm} /$ day) causes substantial change in its morphology. The expanding incised valley and reactivated scarp along the upper section poses a danger to the Hill Cart Road, railway line and the existing settlements. There is every possibility of further sliding and slumping in this area until the slip surface reaches the underlying compact bedrock, $15-30 \mathrm{~m}$ below the present surface (Sarkar, 2011).

The corrective measures that have so far followed in case of Pagla Jahora consist of: a) building up of a retaining wall made of boulders (irrespective of their hardness) at the affected area (Fig. 8) and covering the newly built-up wall with a weir net and b) construction of a number of weepholes in the retaining walls to allow the rain water to flow out. 


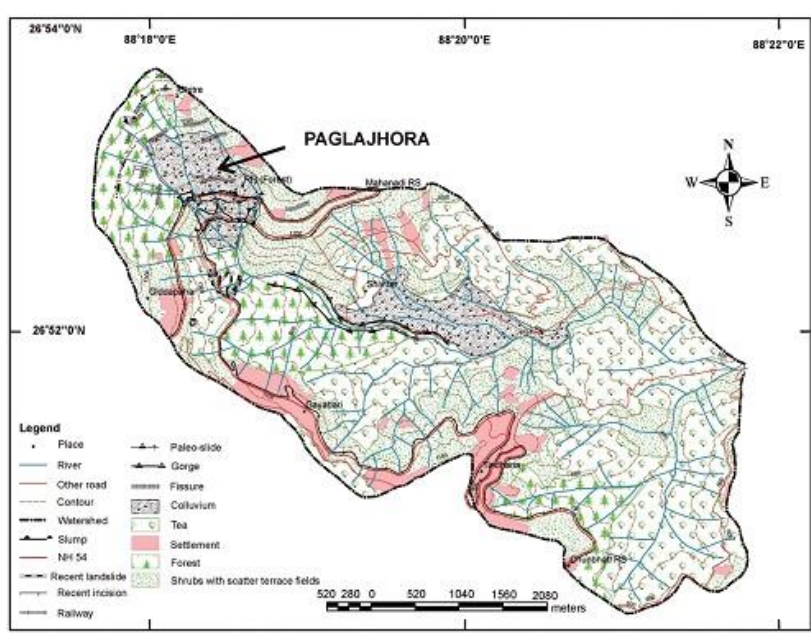

Figure 7 Pagla Jhora landslide in Shiv Khola slump basin

(Sarkar, 2011)

The corrective measures that have so far followed in case of Pagla Jahora consist of: a) building up of a retaining wall made of boulders (irrespective of their hardness) at the affected area (Fig. 8) and covering the newly built-up wall with a weir net and $b$ ) construction of a number of weepholes in the retaining walls to allow the rain water to flow out. With the onset of monsoon and the consequent washing away of the plaster coating of the revetment wall, it was created a passage for the rain water to percolate below which lead to the erosion of the softer veins of the boulders. If one boulder is thus reduced in size creating space for other boulders to roll down by gravity in order to occupy the empty space, the equilibrium of the newly built up revetment wall is thus lost (Fig.9). In such a competition among boulders to occupy the empty space, the wire-net will take too much load concentrated at a particular point, creating a passage through which adjoining boulders will be let loose. Moreover, most of the weep- holes are choked with fine silt or clay after rains and as there is none to clean these, so the free passage of rain water through the retaining wall beeing thus not at all possible. Water is accumulating behind the wall, flows out along the sides of the wall creating deep gullies which ultimately contributeat dislodging the whole retaining wall. In between the upper and lower Pagla Jhora, on the existing road bench of Hill Cart Road, large wide-open arcuate cracks were visible during the landslide disaster of July, 1998
(Basu and De, 2003). Infiltration of surface waters into these cracks, has been visible in many places. Such infiltration increase the pore pressure within the soil on valley sides and was responsible for slope failures in these areas. The south- eastern slopes of Giddha Pahar at about $46 \mathrm{~km}$ from Siliguri shows a surfacial slope failure on the hill slope and subsidence zone towards the valley. These are indicative of the instability of the area and the possible presence of a slip zone below the road bench. A few of the above mentioned areas were affected by the landslide disaster on $13^{\text {th }}$ July, 2003. Some old slides and subsidence zones (Fig.10) in and around Pagla Jhora were reactivated. A major portion of NH55 near Pagla Jhora at $14^{\text {th }}$ Mile had again gone down $15 \mathrm{~m}$ on $8^{\text {th }}$ July, 2004 due to torrential rains which lasted for almost a couple of days. The present condition of NH55 at Pagla Jhora has become so acute that it has been decided by the authority to divert the road along with the railway line for avoiding further disasters.

\subsubsection{Illegal coal mining and the incidences of landslides and subsidence: Tindharia}

Sir Joseph Hooker in 1854, while going to Darjiling, noticed several people burning coal near Pankhabari, for the first time. Mallet ( 1874) while preparing the geological map of Darjiling, identified a narrow band of coal bearing rocks extending between Pankhabari and Dalingkot, covering a length of $37 \mathrm{~km}$. Coal exposures are not continuous everywhere. These are well exposed at Pankhabari, Tindharia, Kalijhora, Bagrakota, Dalingkote and in the valleys of Mahanadi and Tista (Ghosh, 1975; Ghosh, 1998). Due to its flakiness and crushed condition, the former British Government never felt interested in its natural state economic utilization. As such, since 1896 many private firms opened up collieries to extract coals from places like Bagrakota (1896- 1900, extracted about 7231 tonnes of coal), Chunkhola (1943 - 1961, collected 30000 tonnes of coal per year), East Bagrakota (1960 - 62, total production was 25700 - 37200 tonnes), Lethi Colliary (1961-62, total production 900-1200 tonnes) and Fagu Colliary (1962- 63 total production 2600 - 6600 tonnes). 


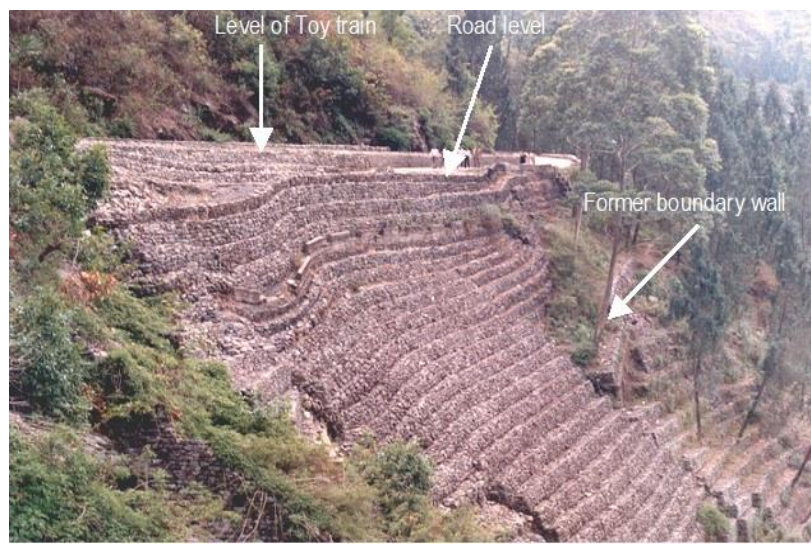

Figure 8 Subsiding Hill-Cart road al Lower Pagla Jhora. The Toy train and the vehicular tracks are at different levels. The former boundary wall of the road is found at a lower level (Photo: S. R. Basu)

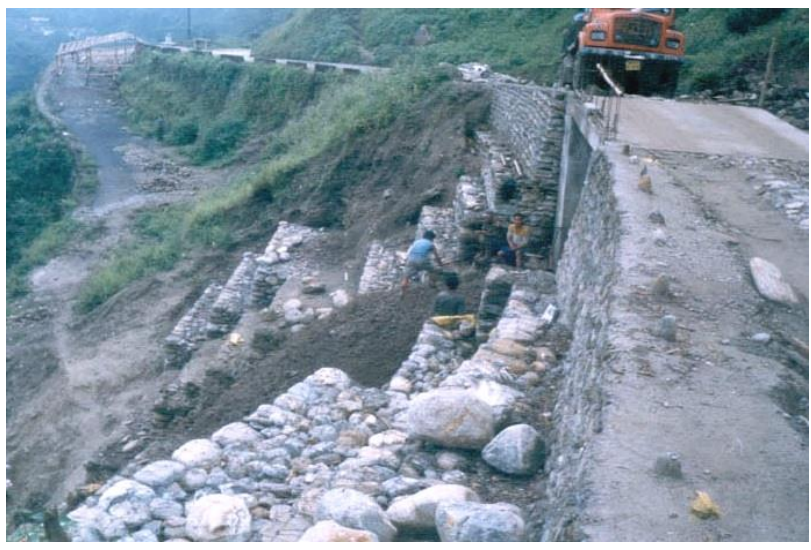

Figure 9 Building the retention wall along the Hill Cart road at Pagla Jhora without any weep hole (Photo: Author)

All these collieries were abandoned in 1964 due to labour-force legal troubles.

The modes of quarry operations in the coal mines mentioned above were introduced by a group of profiteering miners, without following scientific procedures. They punctured the entire slope face with diggings in order to obtain only a few tonnes of coal and did not treat the abandoned pits with any soil conservation method. This eventually led to the innumerable gully erosion formss during rains and disastrous slipping of quite friable and soft Gondwana sandstones and shales. Such conditions not only enhanced the critical conditions of stability of hill slopes, but also provided the tributaries with enormous loads which in turn, have incapacitated the parent river like Lish, causing overflowing of water over the banks, affecting the nearby plains. The disastrous flood of 1968 and 2002 which damaged the Lish road bridge, may be regarded as a typical example in this regard. During non-monsoon months when the discharge of the river Lish remains low, it often gets polluted by the coal-wash water from the remaining mining sites at Chunkhola (Basu, 1998, Basu and Maiti, 2001).

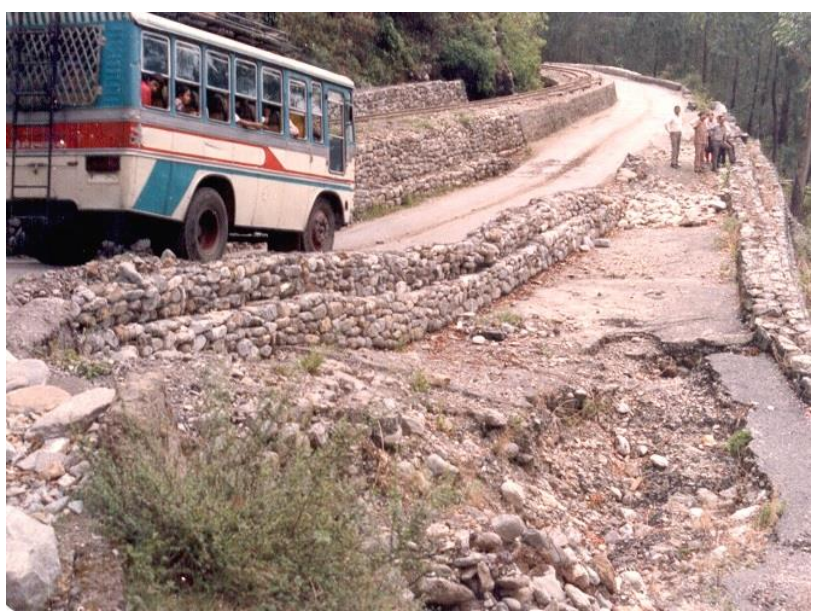

Figure 10 Recurring subsidence of the Hill-Cart road at Pagla Jhora, where the tourist traffic to Darjiling has been badly affected (Photo: Author)
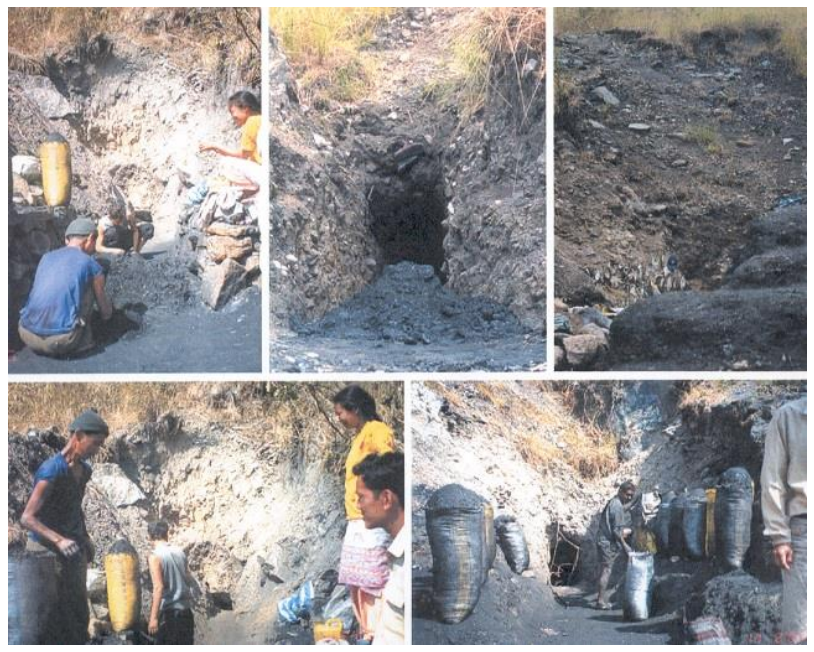

Figure 11 Illegal coal mining at Tindharia by making tunnels in the slope (Photo: S. Sarkar)

During recent observations in Chunkhola (10 $\mathrm{km}$ north of Bagrakot) it has been found out that 
hundreds of people from adjoining area still visit the coal mine daily to collect coal. Part of this coal is used for cooking purpose but the rest is sold to the traders who ultimately sell it to the owners of brick-factories. In Tindharia area, on the way to Darjiling, local people have dug up long tunnels in the local beds of Damuda formation to collect coal illegally at night (Fig.11). Sometimes the roof of such tunnels collapsed injuring the workers. Such examples of landslides were studied in details in works such Basu and Sarkar, 1985, 1988). The Tindharia Cricket Colony, a densely settled area at Tindharia, on the way to Darjiling, has been severely affected by landslides (Fig. 13) induced by subsidence since 1966 (Bhattacharya, 1999) due to coal extraction by drilling tunnels and caves at the base of the Colony. The measured subsidence is about $2.5 \mathrm{~m}$ and due to this the base and the walls of the houses have been broken and tilted dangerously.

\subsubsection{Landslides in tea gardens: Bannockburn Tea Garden and Kurseong Subdivision}

Largely due to the pioneering zeal of the British Planters, the tea industry took firm roots in the district of Darjiling. Started as an experimental plantation in 1840, the tea industry was established as a commercial enterprise by 1856 . In 1885 about 38499 acres came under tea cultivation accounting for an $82 \%$ increase in the cultivated area.

The industry's decline commenced in 1947 when the British Tea Companies suddenly diverted their investments to Africa. Darjiling happens to be the first victim of neglect. The British owners sold off the gardens to the native companies who were motivated towards profit maximization and did not pay any attention to the ecological conditions. This sheer negligence compounded by the unemployment problem, generated the sickness of Darjiling Tea Industry. In 1971, there were 140 operative gardens in the hilly area occupying 63000 acres of land and employing 69000persons. By 1991 the number of operative gardens had come down to 86. Even out of these nearly half of the gardens were either sick or uneconomic. Consequently unemployment problem in the hilly area has increased by leaps and bounds.

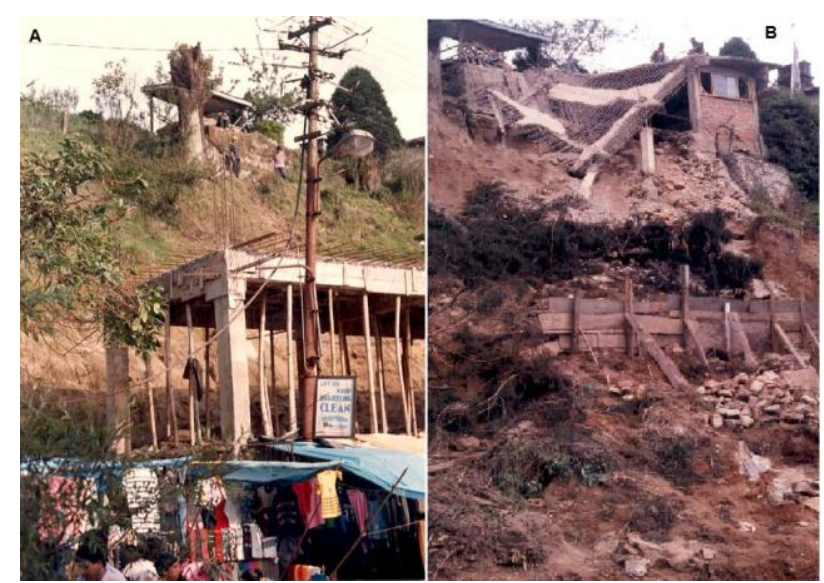

Figure 12 A. Construction of building very close to Belleview hotel in Darjeeling and B. its ill effect endangering the lives and properties of the local inhabitants (Photo: Author)

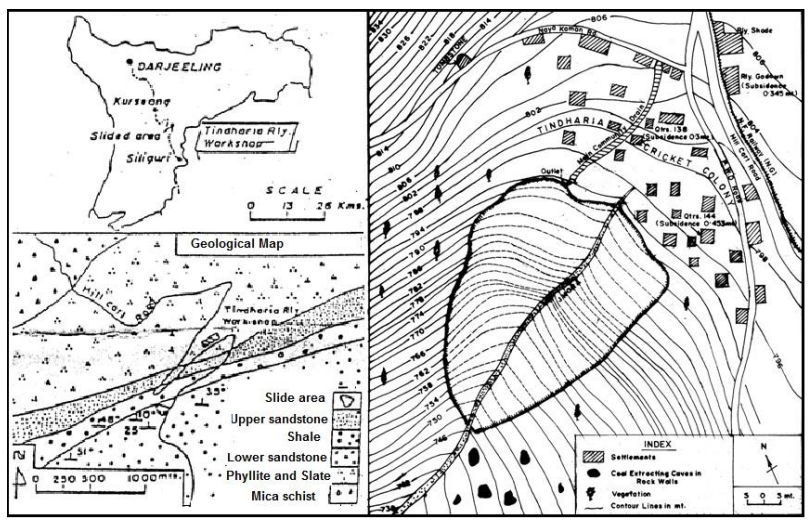

Figure 13 Tindharia Cricket Colony landslide (Basu and Sarkar, 1985)

Table 2 Age classification of plant population for the gardens in Darjiling.

\begin{tabular}{|c|c|c|c|c|c|c|}
\hline $\begin{array}{l}\text { Age of } \\
\text { bushes }\end{array}$ & $\begin{array}{l}<10 \\
\text { yrs. }\end{array}$ & $\begin{array}{l}10- \\
25 \\
\text { yrs. }\end{array}$ & $\begin{array}{c}26- \\
50 \\
\text { yrs. }\end{array}$ & $\begin{array}{c}51- \\
70 \\
\text { yrs. }\end{array}$ & $\begin{array}{l}71- \\
100 \\
\text { yrs. }\end{array}$ & $\begin{array}{c}> \\
100 \\
\text { yrs. }\end{array}$ \\
\hline $\begin{array}{c}\text { Area } \\
\text { (\%) }\end{array}$ & 3.4 & 8.0 & 7.5 & 21.9 & 34.6 & 24.6 \\
\hline
\end{tabular}

Most of the gardens are very old in Darjiling (Table 2). This old age has consequently given rise to shrunken bushes which otherwise would have formed a thick hard canopy and protect the soil of being washed away by the splash of rain. The soil in the area is induced with chemical fertilizers, weedicides and pesticides. These have resulted in the acidic character of the soil and hence have 
made it friable. The ill effect of deforestation for cultivation, grazing, lopping of leaf twigs for fodder and firewood extraction are also factors to reckon with.

\section{Bannockburn Tea Garden}

The garden at Bannockburn bounded by lat. $27^{\circ} 03^{\prime} \mathrm{N}$ and long $88^{\circ} 17^{\prime} \mathrm{E}$ (700-1800 $\mathrm{m}$ a.s.I.) belongs to the oldest category of gardens in Darjiling Himalayas. It is situated in the eastwards exposed valley side of the Rangnu creek. The long step-like slope $\left(10^{\circ}-15^{\circ}\right.$ steep $)$ is dissected by tributary valleys up to $200 \mathrm{~m}$ deep and minor depression appeared as an effect of slides and shallow mudflows. The thickness of regolith deposits varies from seldom bare rocky fragments to $4-10 \mathrm{~m}$ on the gentler parts. At least $60 \%$ of the whole area is occupied by terraced tea plantations, most of them exceeding 500 ha.. On steeper slope there are villages and small gardens. Patches of jungle occupied an area of at least $20 \%$ of the whole garden in 1968, while presently there are only poor remains of bushes used for fodder (Majumder, 2006).

The detailed surveys and measurement of rainfall, infiltration rate and run-off were carried out by Froehlich and Starkel, 1987 and Froehlich et all., in1989. After the heavy rainfall in October 1968 , the seepage pressure was so high, due to the high permeability of the substratum, that hundreds of shallow landslips, mudflows and debris flows occurred, which damaged $20-25 \%$ of the tea gardens. Local downpours exceeding 200-300 mm have caused the reactivation of numerous slides on the steep slopes or the occurence of new ones in 1983 and 1987.

Summarizing the aforesaid facts it may be said that in this garden the slides have been initiated since 1950 and reactivated in 1968 1980, 1983, 1987, and 1990 due to catastrophic rainfall. Maps showing the change in forest cover, landuse and landslide incidences have been detailed since 1931 up to 2001 (Fig. 14).

\section{Kurseong Subdivision}

A total number of 32 tea gardens have been inventoried in the Kurseong Subdivision, most of which are free from any landslide event (Fig. 15).
Out of the 80 landslides in the whole study area, only 17 landslides are occurring in tea gardens, among which Ambootia and Gayabari landslides proved to be devastating.

The hill-slopes in and around Kurseong, Mirik and Gayabari were seriously affected by landslides due to heavy rainfall between October 2-5, 1968 (Starkel and Basu, 2000, ). The severity of landslides in that year was so high that the whole hilly area was totally cut-off from the surrroundings for about a week. Ambootia, the most dangerous and largest landslide in Darjiling Himalayas occured in that year (Froehlich, et.al., 1991). Severe landsliding phenomena again occurred between September 34, 1980 and have been continuing till today. On July 8, 2003 at about 3.30 a.m. a (previously-mentioned) major landslide occurred at Gayabari Bustee, during which four hamlets were destroyed and twelve lives were lost. A concentrated rainfall of over $300 \mathrm{~mm}$ during a period of over 48 hours saturated the soil covering Damuda and Daling series and activated the debris slides (De, 2011). Moreover, recently the thick soil has been unscientifically utilized for the cultivation of ginger, whose harvesting during the monsoon season disturbs the cohesiveness of soil and aggravates soil erosion and shallow landsliding.

\subsubsection{Landslides at urban agglomeration: Darjiling Town}

Landslides could be considered perhaps the most rampant environmental hazards threatening the town of Darjiling.. Many times during or after the monsoon season, landslides create havoc in and around Darjiling township area. Numerous slides have occurred in the past and the intensity cause and severity level of the slides are being recorded since 1899. The records of recent landslide revealed clearly that the slides frequency is presently increasing year after year.

Up to the first half of the XXth century there were certain regulations for the commercialization of the hill slopes, but since India's independence, in a desperate attempt to acquire as much arable land as possible, extensive areas covered by forests were gradually encroached upon. 


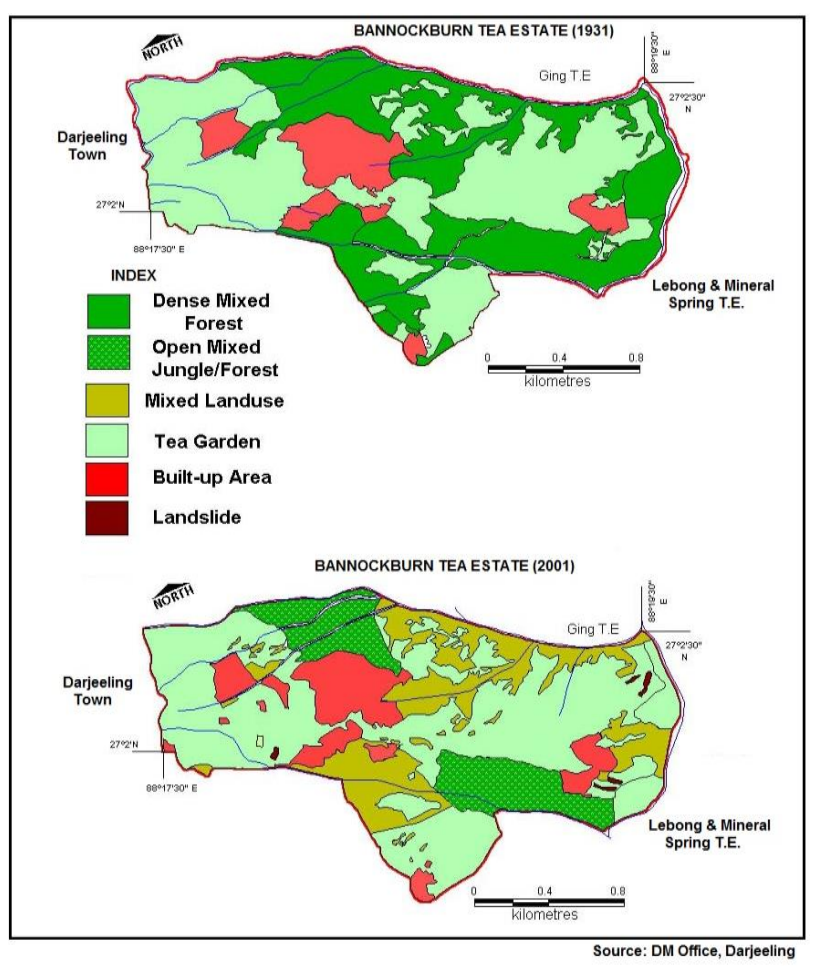

Figure 14 Changes in land-use/land-cover in Bannockburn Tea Estate

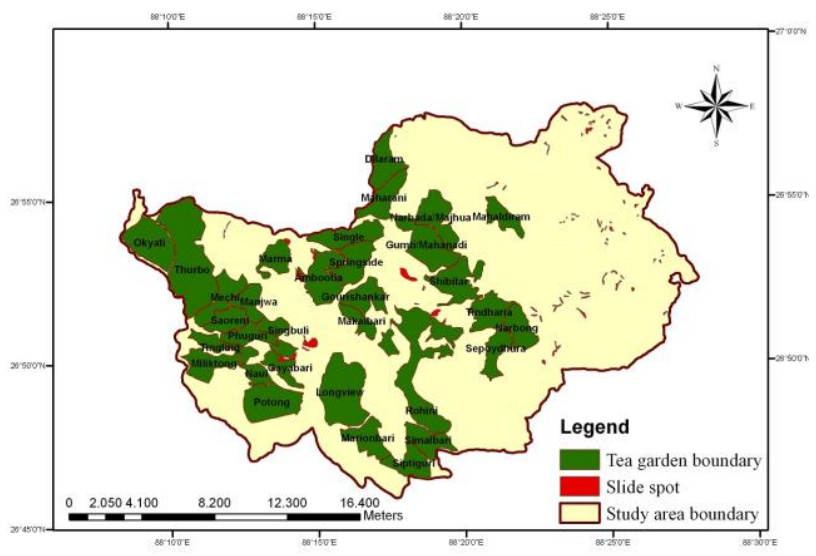

Figure 15 Distribution of landslides in different tea gardens of Kurseong subdivision

The ever-increasing number of people haphazardly settled in an every bit of land available. During the British period it was stated that forest on the upper part of the hills should not be brought under ordinary commercial forest management. But after independence, the demand for timber increased at an unprecedented rate and even the upper layer of the forest was not spared. Even after a mass afforestation programme have been implemented, a big gap remains between felling and replanting. It has been estimated that $70 \%$ of the cooking energy needs of the people are being met by firewood. Thus, a reckless obliteration of forests along with unscientific use of slopes (especially in construction works coupled with geological, rainfall and slope characteristics) have changed the scenario completely. As a result, Darjiling, one of the most densely populated tourist centre in comparable environment exits on the verge of an environmental catastrophe as with just one concentrated shower of $50 \mathrm{~mm} / \mathrm{h}$ would initiate numerous landslides endangering the lives and properties of the local inhabitants (Fig. 12). For better understating of landslide hazard in Darjiling town and following an expert-based approach, a landslide susceptibility zonation map including the corresponding landslide distribution has been prepared (Fig. 16)

\section{Conclusion and suggestive measures}

From the above study it becomes apparent that the nature of landslide varies in proportion in various localities in Darjiling Himalayas Hills. The high intensity of rainfall, extreme deforestation, vulnerable geological structures and overall human interference are the most important triggering, preparing and predisposing factors of such processes. The problems to be tackled immediately are summarized below:

- The protection of the whole Pagla Jhora valley would be extremely difficult not only for the high cost involved but also for the continuous down cutting and undermining of the slope from the base and the high delivery of coarse debris from the upper slopes during rains. So, while taking corrective measures, the authorities concerned will have to be very careful and follow a scientific method in preventing such slope failures. Moreover, the revetment walls and their surroundings should carefully be afforested preferably with local varieties of grass, bamboo or wild fern which can protect the slope better from the splashing of rains. 


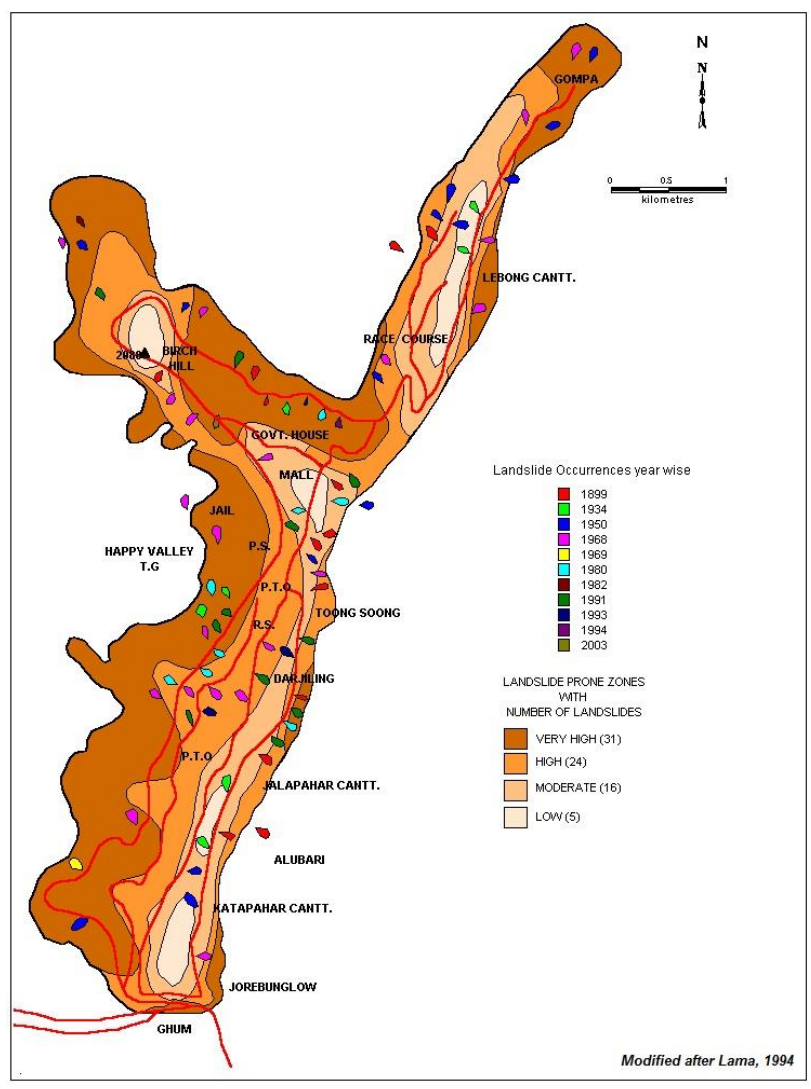

Figure 16 Landslide susceptibility zones along with the distribution of landslide occurrences

- The people of the localities should be provided with some alternate sources of energy through construction of Mini-Hydel Projects utilizing the voluminous discharge of the springs (e.g. Pagla Jhora), which can be an option to prevent them from cutting down more trees and digging out coal for fuel thus disturbing the natural slopes. Otherwise, allowing the springs to flow freely across the roads and causing soil erosion and subsidence, the protection of transportation routes to Darjiling (for both tourists as well as permanent settlers) will be endangered.

- In case of the Tea Gardens (e.g. Bannockburn) shrinkage of the old bushes is giving way to intense rainfall thus resulting in the formation of gullies, which have been considered to be the main causes of soil erosion and landslides since 1950. Catastrophic rainfall of 1968 reactivated almost all of the dormant mass movements. Later on many more spots were affected during the intense rainfalls of 1983, showing that the cause of such menace remains to be the same.

- In view of the ever increasing problems of landslides in Darjiling Town, one must be aware of the possible dangers that the human is inviting due to its careless dealing with nature. It is true that one has to make room for the growing population and in this pursuit he has to utilize every piece of land available. But the precautions that have to be adopted should not be neglected. In the town, the revetments are not properly maintained, the weepholes are choked and drains are dumped with garbage, restricting free drainage of water. Moreover, the present landuse system should properly be evaluated and the construction of high rise buildings should be controlled immediately. But above all it should be of extreme importance to develop awareness among the local people and the tourists, so that they perceive the existing ecological imbalances and take proper care to maintain an eco-friendly atmosphere in the said locality.

\section{Acknowledgement}

The author started this work with Late Prof. S. R. Basu. Due to his untimely demise the work remained incomplete for several years. The author gratefully acknowledges the contribution and motivation of Late Prof. S. R. Basu in completing this work.

\section{References}

Basu SR. 1998. Mining and Environment: a few case studies in the Eastern Himalayas; The Geographer, Aligarh Muslim University, India, Vol. XLV, No. 2, pp. $41-55$

Basu SR and De SK 2003. Causes and consequences of Landslides in the Darjiling \& Sikkim Himalayas, India, Geographia Polonica, Poland, Vol. 76, No. 2, pp 37 57.

Basu SR and Sarkar S. 1985. Some consideration on recent landslides at Tindharia and their Control; Indian Journal of Power and River Valley Development, Oct.-Nov., pp. 45-53

Basu SR and Sarkar S. 1988. Eco-system vis-à-vis landslides - a case study in Darjeeling Himalayas. Proceedings of the National Conference on Impact of 


\section{Landslides and human interference in Darjiling Himalayas, India}

Development on Environment, Geographical Society of India, Calcutta, Vol.-II, pp. 45-50

Basu SR. 2000. Causes of Landslides in the Darjeeling Town of Eastern Himalayas, in E. Bromhead and others (eds.), Landslides in research, theory and practice, Thomas Telford, Cardiff U.K. Vol.-1, 133-138

Basu SR. 2001. A systematic study of landslides along the arterial routes to Darjeeling and their control, (in) Ho \& Li (eds.), Geotechnical Engineering-Meeting Society's Needs, Hong Kong, pp. 691-695

Basu SR. and Maiti RK. 2001. Unscientific, mining and degradation of slopes in the Darjeeling Himalayas, Changing Environmental Scenario of the Indian Subcontinent (Ed), pp.- 390-399.

Bhattacharya A, Mishra P, Ghoshal TB, Bahuguna $H$ \& Ghatak T. 1998. A Geotecnical appraisal of landslides on $7^{\text {th }}$ July, 1998 along National Highway No. 55; Unpublished report of the Geological Survey of India, pp. 1-22

Bhattacharya S. 1999. Tindharia Cricket Colony landslide in Darjeeling Hills- a comparative account, 1996 2001; In Basu, S.R. (ed.) Changing Environmental Scenario of the Indian Subcontinent, acb publications, Calcutta, pp 400 - 405

De SK, Bandyopadhyay S, Jamatia, M. 2011. Landslides in Tea Gardens: A study on the Kurseong sub-division of Darjeeling Himalayas, India. In Cloud Stone and the Mind: The People and Environment of Darjeeling Hill Area (Ed. by Desai, M. \& Mitra, S.). K.P. Bagchi \& Co., Kolkata, pp 25-38 (ISBN: 978-81-7074-328-6).

Froehlich W, Starkel L, Kasza I. 1991. Ambootia landslides valley in the Darjeeling Himalaya active since 1968.
Bulletin of the Polish Academy of Sciences, Series: Earth Sciences 39 (2), 111-128.

Froehlich W and Starkel L. 1987. Normal and extreme monsoon rains - their role in the shaping of the Darjeeling Himalaya. Studia Geomorph. Carpatho Balc. Vol. 21, pp. 129-160

Froehlich W, Gil E, Kasza I \& Starkel L. 1989. Thresholds in the transformation of slopes and river channels in the Darjeeling Himalaya; Studia Geomorphologica Carpatho-Balcanica, Krakow, Vol. XXIII, pp. $105-121$

Ganssar A. 1964. Geology of the Himalayas. J. Wiley, New York, p 289.

Ghosh R. 1998. Environmental impact on coal mining in Jharia Coal Field, Eastern India- its past, present \& future; Trans. Min. Geol. Metall. Inst. India, Vol 85 (2), pp. 78 - 98

Ghosh TK. 1975. Petrography and metamorphism of Darjeeling Coal, Eastern Himalayas, India; N.Jb. Palolaont, MG. H. 7, pp. 339 - 408

Majumdar P. 2006. Urbanization and Environment Degradation in Darjeeling P.S. of West Bengal, unpublished Ph.D. thesis, Calcutta University, West Bengal.

Mallet FR. 1874. On the geology and mineral resources of the Darjeeling District and the western duars, Memoir, G.S.I., Vol. 11(1), p. 72

Sarkar S. 2011. Evolution of the Paglajhora Slump valley in the Upper Shiv Khola basin, The Darjeeling Himalaya, India. Geographia Polonica, 84 (2): 117-126.

Starkel L and Basu SR. 2000. Rains, Landslides and Floods in the Darjeeling Himalayas. Indian National Science Academy, New Delhi, 1-168. 